\title{
DISTRIBUSI JALAK BALI (Leucopsar rothschildi) DI KEPULAUN NUSA PENIDA
}

\section{DISTRIBUTION OF BALI STARLING (Leucopsar rothschildi) IN NUSA PENIDA ISLAND}

\author{
FX. Sudaryanto ${ }^{1}$, Jusup Subagja ${ }^{2}$, Satyawan Pudyatmoko ${ }^{3}$, Cut Sugandawaty Djohan ${ }^{2}$ \\ ${ }^{1}$ Laboratorium Taksonomi Hewan Program Studi Biologi Fakultas MIPA Universitas Udayana. \\ ${ }^{2}$ Laboratorium Ekologi dan Konservasi Fakultas Biologi Universitas Gadjah Mada \\ ${ }^{3}$ Laboratorium Satwa Liar Fakultas Kehutanan Universitas Gadjah Mada \\ Email: sudaryanto@unud.ac.id
}

\section{INTISARI}

Jalak Bali (Leucopsar rothschildi Stresemann, 1912) adalah burung endemik Pulau Bali. Sejak tahun 1966 Jalak Bali dimasukkan ke dalam kategori kritis (Critically endangered) IUCN Red List of Threatened Species, dan Peraturan Pemerintah Republik Indonesia Nomor 7 tahun 1999 tentang Pengawetan Jenis Tumbuhan dan Satwa. Konservasi Jalak Bali yang telah dilakukan di Taman Nasional Bali Barat ternyata belum berhasil. Oleh sebab itu, mulai tahun 2006 usaha konservasi Jalak Bali juga dilakukan di Kepulauan Nusa Penida. Penelitian ini bertujuan mempelajari distribusi Jalak Bali di Kepulauan Nusa Penida. Untuk mengetahui distribusi Jalak Bali dilakukan penjelajahan dan wawancara dengan masyarakat setempat. Hasilnya distribusi Jalak Bali pada tahun 2006 hanya 3 lokasi di Pulau Nusa Penida, pada tahun 2015 telah menjadi 12 lokasi, 2 lokasi di Pulau Nusa Lembongan dan 9 lokasi di Pulau Nusa Penida.

Kata kunci: Jalak Bali, Leucopsar rothschildi, Kepulauan Nusa Penida, Bali, distribusi.

\section{ABSTRACT}

Bali Starling (Leucopsar rothschildi Stresemann, 1912) is endemic bird to the Bali Island. Since 1966, Bali Starling has been categoried as Critically Endangered by the IUCN Red List of Threatened Species, and the Indonesian Government Regulation No. 7 of 1999 on Preservation of Fauna and Flora. Conservation of Bali Starling has been done in the Bali Barat National Park, but has not succeeded yet. Therefore, starting in 2006 the conservation of the Bali Starling is also done in the Nusa Penida Islands, Klungkung Regency. To examine the successful of conservation of Bali Starling in Nusa Penida Islands, need the studies as follows: How is the distribution of Bali Starling? This research aims to study the success of conservation of Bali Starling in Nusa Penida Island. Specifically, the purpose of this research were to study distribution of Bali Starling. Materials and methods used in this research was known from questioned to the people in the area, and also conducted exploration. Distribution of Bali Starling in 2006 was only in three locations, and being expanded in 2015 there were at least in 12 locations.

Keywords: Bali Starling, Leucopsar rothschildi, Nusa Penida Island, Bali, distribution

\section{PENDAHULUAN}

Jalak Bali (Leucopsar rothschildi Stresemann, 1912) adalah burung endemik Pulau Bali, dan distribusinya sampai tahun 2005 hanya ada di Taman Nasional Bali Barat (TNBB). Jalak Bali pertama kali ditemukan oleh Erwin Stresemann pada tahun 1911 di Desa Bubunan, Kecamatan Seririt, Kabupaten Buleleng, Provinsi Bali. Namun, burung - burung tersebut pada tahun 1950-an sudah tidak terlihat lagi di Bubunan Buleleng. Sementara itu tahun 1960-an Jalak Bali masih terdapat di Selemadeg Tabanan, pada tahun 1980-an di Melaya Jembrana, dan pada tahun 1990-an burung tersebut masih ditemukan di Pupuan Tabanan. Pada tahun 2000-an hanya terdapat di Pos Brumbun sampai Pos Lampu Merah TNBB, bahkan pada tahun 2014 Jalak Bali hanya terdapat di Pos Lampu Merah TNBB (Gambar 1) (Van Balen dkk., 2000; Sudaryanto dkk., 2015).

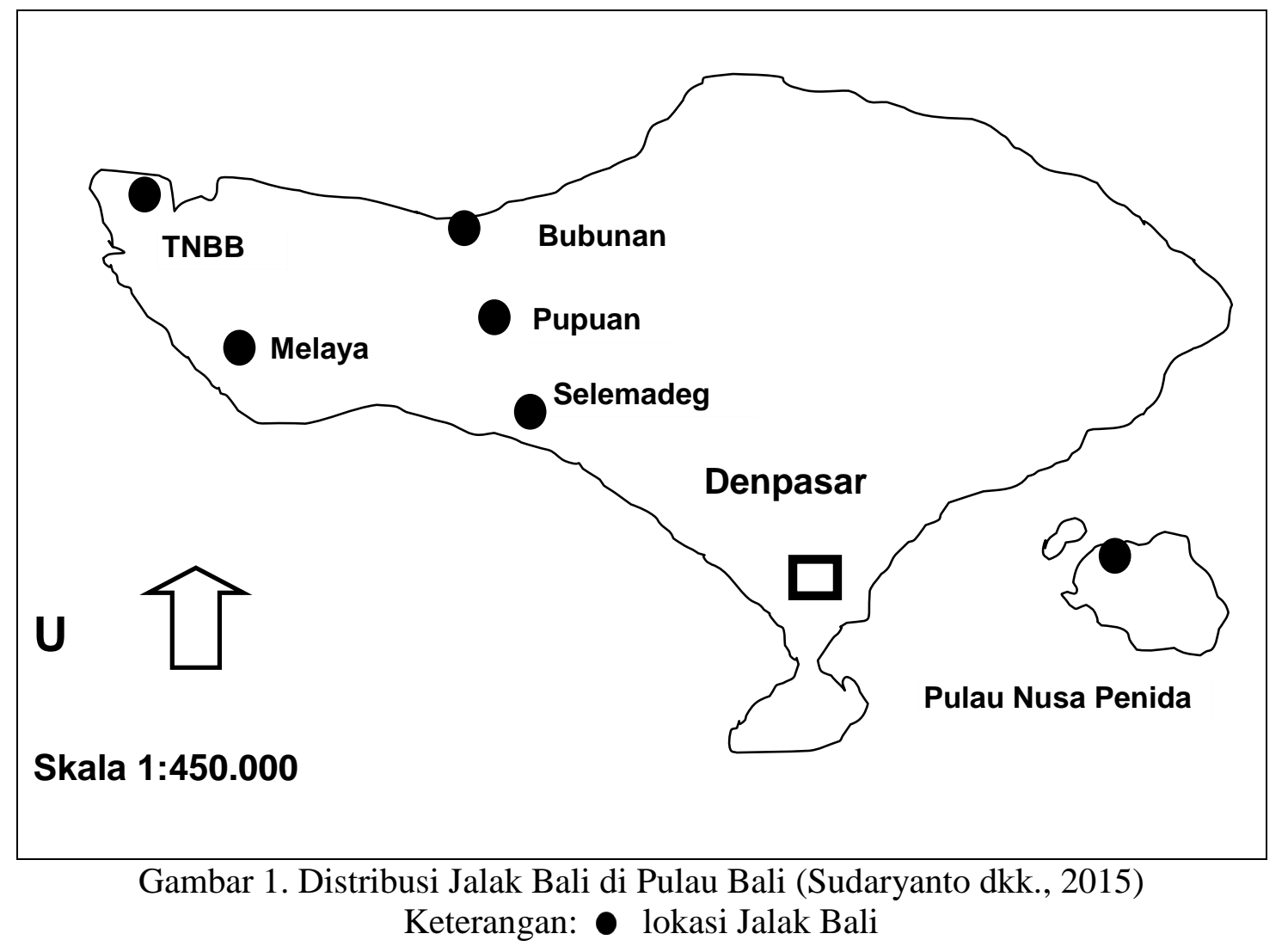

Selain itu, Schmidt (1983) menduga bahwa selain di Pulau Bali distribusi Jalak Bali juga terdapat di Pulau Nusa Penida.Jalak Bali menghadapi risiko kepunahan yang sangat tinggi di TNBB, karena banyak terjadi pencurian. Menurut Van Balen dkk (2000), tahun 1960-1980 ratusan Jalak Bali banyak dijual di negara-negara Eropa. Oleh karena itu, sejak tahun 
1966 Jalak Bali dimasukkan ke dalam kategori kritis (Critically endangered) oleh IUCN Red List of Threatened Species. Selain itu, CITES memasukkan burung tersebut ke dalam Appendix I. Jalak Bali dilindungi Pemerintah Indonesia dengan Surat Keputusan Menteri Pertanian No. 421/Kpts/Um/8/1970, kemudian juga Peraturan Pemerintah Republik Indonesia Nomor 7 tahun 1999 tentang Pengawetan Jenis Tumbuhan dan Satwa (Anonymous, 1999; 2012a; 2012b; Van Balen dkk. 2000; Sodhi dkk. 2004; Jepson dan Ladle, 2005,2008; Sodhi dan Smith, 2007; Jepson dkk. 2008; Widodo, 2014; Jepson, 2015; Ardana dan Rukmana, 2017).

Konservasi Jalak Bali yang telah dilakukan di TNBB selama ini belum berhasil. Oleh karena itu, sejak tahun 2006 usaha konservasi Jalak Bali juga dilakukan oleh FNPF di Kepulauan Nusa Penida Kabupaten Klungkung Provinsi Bali. FNPF (Friends of the National Parks Foundation) adalah suatu Lembaga Swadaya Masyarakat (LSM) lokal di Bali. Konservasi Jalak Bali di Kepulauan Nusa Penida dilakukan FNPF, bekerjasama dengan Pemerintah Provinsi Bali dan Universitas Udayana. FNPF telah melakukan kajian sejak tahun 2004, yaitu inventarisasi vegetasi penghasil makanan Jalak Bali, dan sosialisasi kepada masyarakat. Sosialisasi kepada masyarakat Kepulauan Nusa Penida tentang pelepasliaran Jalak Bali, dan perlindungan burung khususnya Jalak Bali. Selain itu, FNPF bekerjasama dengan Lembaga Adat tingkat Kecamatan Nusa Penida, Kabupaten Klungkung, dan Provinsi Bali. Tujuannya untuk memasukkan perlindungan burung, khususnya Jalak Bali, di dalam awig-awig (hukum adat) Desa Adat di seluruh Kepulauan Nusa Penida (Wirayudha, 2007).
Tujuan penelitian ini adalah untuk mempelajari konservasi Jalak Bali di Kepulauan Nusa Penida. Secara spesifik, tujuan penelitian ini untuk mempelajari distribusi Jalak Bali di Kepulauan Nusa Penida,

\section{BAHAN DAN METODE}

\section{Alat}

Pengamatan burung menggunakan teropong binokuler (binocular telescope) merk Pegasus $8 \times 42$. Juga kamera Canon SX50HS dengan resolusi 12 1MP serta 50x optical zoom $(24 \mathrm{~mm}$ to $1200 \mathrm{~mm})$ dan $24 \mathrm{~mm}$ ultra wide angle. Untuk mendengarkan suara burung menggunakan Action Ear. Lokasi perjumpaan dengan Jalak Bali ditentukan dengan Global Positioning System (GPS) merk Garmin 60 CSx, kemudian lokasi tersebut ditandai dengan cat. Peta Pulau Bali skala 1:175.000 terbitan Badan Informasi Geospasial.

\section{Deskripsi Lokasi Penelitian}

Kepulauan Nusa Penida terletak $20 \mathrm{~km}$ ke arah tenggara dari Pulau Bali pada koordinat $8^{\circ} 38^{\prime} 58,04^{\prime \prime}-8^{\circ} 49^{\prime} 30,03^{\prime \prime}$ LS; $115^{\circ} 25^{\prime} 14,01^{\prime \prime}-115^{\circ} 38^{\prime} 22,32^{\prime \prime}$ BT. Kepulauan Nusa Penida terdiri dari tiga pulau yaitu: Pulau Nusa Penida dengan luas 20.000 ha, yaitu hutan 1.000 ha, dan sisanya wanatani (agroforestry). Pulau Nusa Lembongan luasnya 1.000 ha, yaitu hutan bakau luas 200 ha dan sisanya, wanatani, sedangkan luas Pulau Nusa Ceningan 300 ha. Kepulauan Nusa Penida secara administratif termasuk Kecamatan Nusa Penida, Kabupaten Klungkung, Provinsi Bali (Anonymous, 2013).

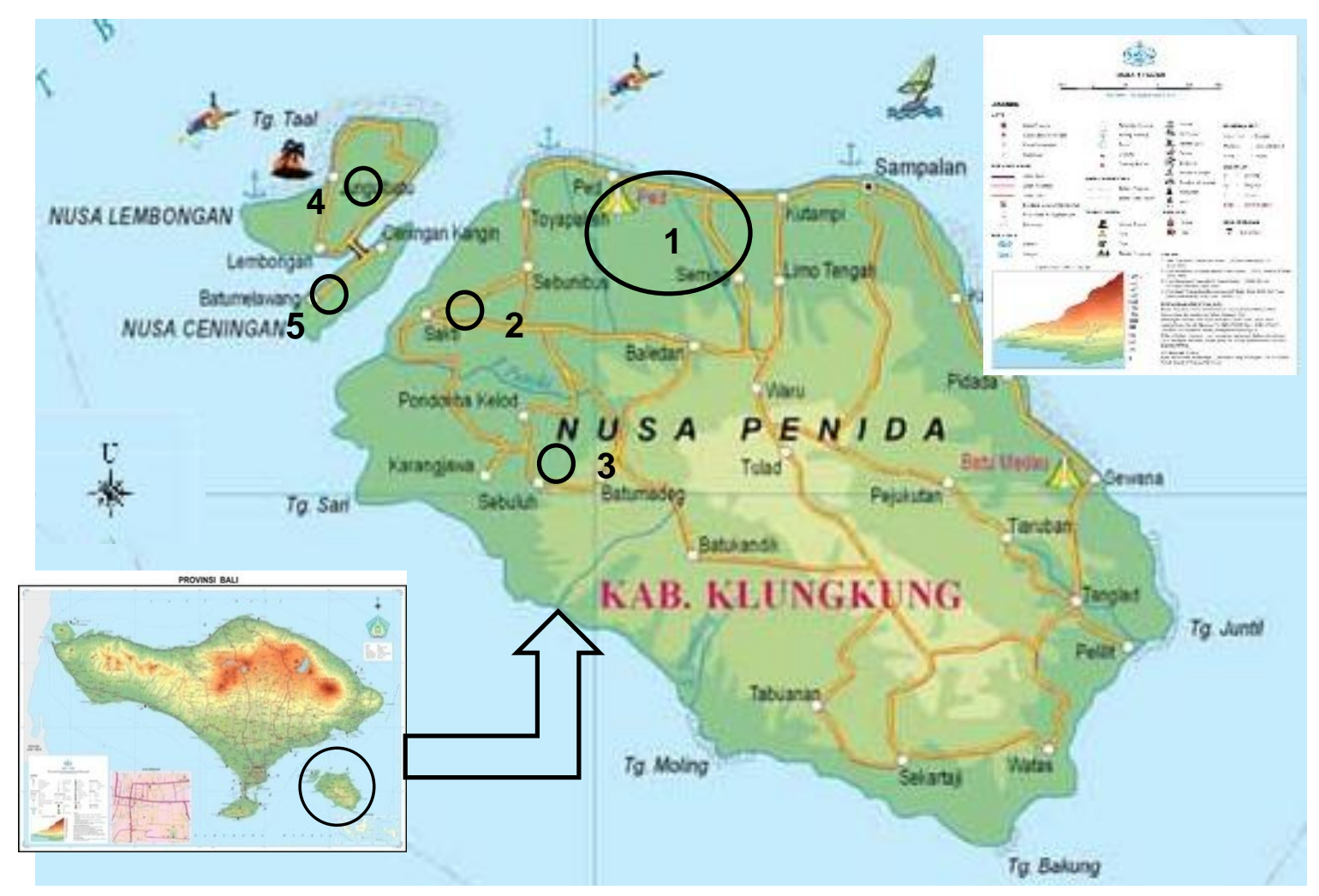

Gambar 2. Distribusi Jalak Bali di Pulau Nusa Penida: 1. Desa Ped, 2. Desa Sakti, 3. Desa Batumadeg. Pulau Nusa Lembongan: 4. Desa Jungut Batu. 5. Pulau Nusa Cenimgan.

\section{Rancangan Penelitian}

Penelitian distribusi Jalak Bali dilakukan dari tahun 20062015, di Kepulauan Nusa Penida yaitu di Pulau Nusa Penida, Pulau Nusa Lembongan, dan Pulau Nusa Ceningan. Untuk mengetahui distribusi Jalak Bali di Kepulauan Nusa Penida dilakukan penjelajahan dan wawancara dengan masyarakat di daerah tersebut (Alikodra, 1990). Penelitian terutama dilakukan di Pulau Nusa Penida: 1. Desa Ped, 2. Desa Sakti, 3. Desa Batumadeg. Pulau Nusa Lembongan: Desa Jungut Batu dan di Pulau Nusa Cenimgan (Gambar 2).

\section{HASIL DAN PEMBAHASAN}

Pelepasliaran Jalak Bali di Kepulauan Nusa Penida pertama kali dilakukan pada tanggal 13 Juni 2006 di Kantor Friends of National Park Foundation (FNPF) Banjar Bodong Desa Ped Pulau Nusa Penida sebanyak dua ekor. Sebelum pelepasliaran tersebut, di Kepulauan Nusa Penida tidak ada Jalak Bali. Selanjutnya, perilaku mencari makan diamati, yaitu makan buah dan serangga. Setelah hasil pengamatan dievaluasi, Jalak Bali dianggap dapat beradaptasi dengan habitat di Pulau Nusa Penida. Oleh karena itu, dimulailah 
program pelepasliaran Jalak Bali di Kepulauan Nusa Penida (Tabel 1).

Pada tanggal 10 Juli 2006 Jalak Bali dilepasliarkan di Pura Penataran Ped 10 ekor, dan di Batumadeg 15 ekor. Desa
Ped adalah daerah wanatani, penduduknya 500 orang $/ \mathrm{km}^{2}$. Selain itu, Batumadeg (239 m dpl) juga daerah

Tabel 1. Pelepasliaran Jalak Bali di Kepulauan Nusa Penida

\begin{tabular}{|c|c|c|c|c|c|}
\hline No & $\begin{array}{c}\text { Tanggal } \\
\text { Melepaskan }\end{array}$ & $\begin{array}{c}\text { Tempat } \\
\text { Melepaskan }\end{array}$ & $\begin{array}{c}\text { Yang } \\
\text { Melepaskan }\end{array}$ & $\begin{array}{c}\text { Cacah } \\
\text { individu } \\
\text { (ekor) }\end{array}$ & Keterangan \\
\hline 1 & $13 / 6 / 2006$ & Kantor FNPF & FNPF & 2 & - \\
\hline \multirow[t]{2}{*}{2} & \multirow[t]{2}{*}{$10 / 7 / 2006$} & Desa Ped $^{1}$ & \multirow[t]{2}{*}{ Gubernur Bali } & 10 & - \\
\hline & & Desa Batu Madeg & & 15 & Mati 2 ekor \\
\hline 3 & $12 / 12 / 2006$ & Desa Batu Madeg & $\mathrm{FNPF}^{2}$ & 12 & - \\
\hline 4 & 27/4/2007 & Pelabuhan Kutampi & Presiden RI & 12 & Mati 2 ekor \\
\hline 5 & $25 / 7 / 2007$ & Desa Ped $^{1}$ & MenHut RI & 2 & - \\
\hline 6 & $20 / 12 / 2012$ & $\begin{array}{l}\text { Pura Puaji } \\
\text { Nusa Lembongan }\end{array}$ & FNPF & 6 & - \\
\hline 7 & $31 / 12 / 2013$ & Desa Sakti & MenHut RI & 2 & - \\
\hline 8 & $18 / 10 / 2014$ & Desa Ped $^{1}$ & Bupati Klunkung & 4 & - \\
\hline & & & Jumlah & 65 ekor & Mati 4 ekor \\
\hline
\end{tabular}

Keterangan:

${ }^{1}$ Pura Penataran Ped Pulau Nusa Penida
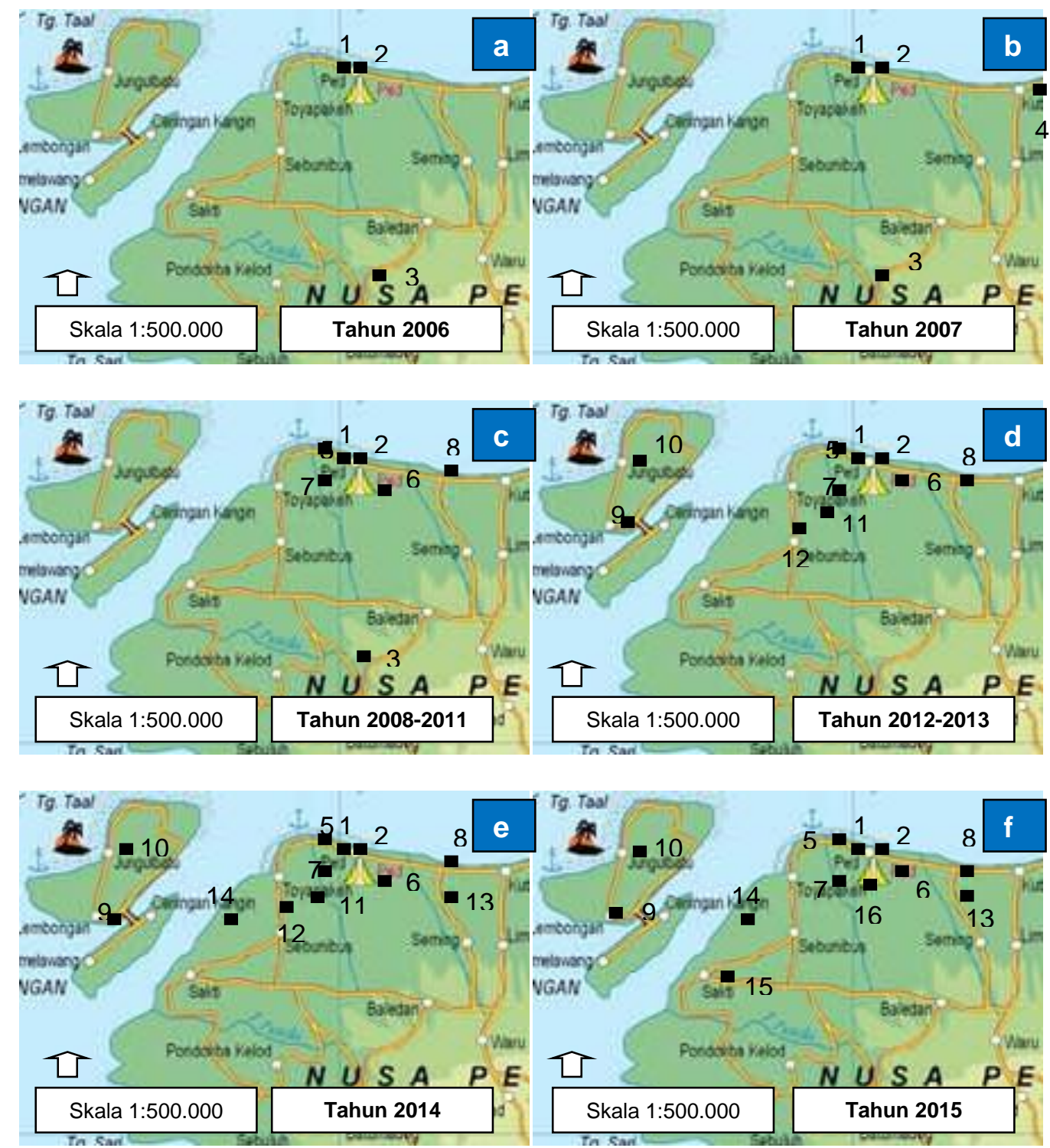

Gambar 3. Distribusi Jalak Bali di Kepulauan Nusa Penida tahun 2006-2015

(a) tahun 2006, (b) tahun 2007, (c) tahun 2008-2011, (d) tahun 2012-2013,

(e) tahun 2014, (f) tahun 2015. (1) FNPF, (2) Pura Penataran Ped, (3) Batumadeg,

(4) Kutampi, (5) Pura Dalem Bungkut, (6) Pura Puseh, (7) Pura Tinggar, (8) Sental Kawan,

(9) Lembongan, (10) Pura Puaji, (11) Biaung, (12) Sebunibus, (13) Sental Kangin,

(14) Penida, (15) Sakti, (16) Klibun. : lokas」Jalak Bali.

wanatani, penduduknya 170 orang/ $/ \mathrm{km}^{2}$ (Anonymous, 2013). Pada tahun 2006, keberadaan Jalak Bali di Pulau Nusa Penida terdapat di tiga lokasi, yaitu FNPF (2 ekor), Pura Penataran Ped (10 ekor), dan Batumadeg (25 ekor) (Gambar 3a).

Pada tahun 2007, Presiden Republik Indonesia melepasliarkan Jalak Bali di Pelabuhan Kutampi (5 m dpl). Pelabuhan Kutampi terletak satu kilometer di timur Pura Penataran Ped. Jalak Bali yang dilepasliarkan di Pelabuhan
Kutampi sebanyak 6 pasang, tetapi 2 ekor burung tercebur ke laut dan mati. Beberapa Jalak Bali di Pura Penataran Ped berpindah ke FNPF karena vegetasi di FNPF lebih banyak tersedia makanan. Kantor FNPF seluas 1 ha didominasi bunut (Ficus glabella), mangga (Mangifera indica), kersen (Muntingia calabura), jari (Tectona grandis) yang banyak terdapat serangga dan buah makanan utama Jalak Bali. Pada tahun 2007, keberadaan Jalak Bali menjadi empat lokasi, yaitu 
FNPF, Pura Penataran Ped, Batumadeg, dan Pelabuhan Kutampi (Gambar 3b).

Pada tahun 2008 seluruh Jalak Bali di Pelabuhan Kutampi berpindah ke Sental Kawan (17 m dpl) karena vegetasi di Sental Kawan lebih banyak tersedia makanan. Sental Kawan adalah daerah perbukitan berupa wanatani, dan terdapat banyak pohon bunut, dan terletak antara Pelabuhan Kutampi dengan Pura Penataran Ped, dengan jarak masingmasing $500 \mathrm{~m}$. Beberapa Jalak Bali di Pura Penataran Ped berpindah ke Pura Puseh, karena vegetasinya lebih banyak tersedia makanan. Pura Puseh $(68 \mathrm{~m} \mathrm{dpl})$ adalah perbukitan yang terletak $300 \mathrm{~m}$ di selatan Pura Penataran Ped, yang vegetasinya didominasi jati dan bunut. Jalak Bali di FNPF sebagian berpindah ke Pura Dalem Bungkut karena ada kompetisi intraspesies. Selanjutnya, sebagian Jalak Bali di Pura Dalem Bungkut berpindah ke Pura Tinggar karena juga ada kompetisi intraspesies. Pura Tinggar $(68 \mathrm{~m} \mathrm{dpl})$ terletak $500 \mathrm{~m}$ sebelah tenggara Pura Dalem Bungkut. Sental Kawan, Pura Puseh, Pura Dalem Bungkut, dan Pura Tinggar adalah daerah wanatani dan kebun kelapa. Pada umumnya Jalak Bali berpindah tempat dalam kelompok kecil, 2 sampai 4 ekor burung. Lokasi baru Jalak Bali berjarak 100-300 m dari lokasi lama. Kalau lokasi baru berjarak cukup jauh, maka perpindahan itu dilakukan selama beberapa tahap.

Pada tahun 2008-2011, keberadaan Jalak Bali bertambah empat lokasi (Sental Kawan, Pura Puseh, Pura Dalem Bungkut, dan Pura Tinggar) dan berkurang satu lokasi (Pelabuhan Kutampi). Jadi pada tahun 2008-2011, keberadaan Jalak Bali di Pulau Nusa Penida terdapat di tujuh lokasi, yaitu FNPF, Pura Penataran Ped, Batumadeg, Pura Dalem Bungkut, Pura Puseh, Pura Tinggar, dan Sental Kawan (Gambar 3c). Keberadaan Jalak Bali ini memperluas penyebaran, dibandingkan tahun 2007 yang hanya empat lokasi.

Pada tahun 2012-2013, Jalak Bali di Batumadeg berpindah ke Sebunibus (155 m dpl) dan Biaung (105 m dpl). Jarak Batumadeg-Sebunibus kira-kira $2.500 \mathrm{~m}$, dan jarak Batumadeg-Biaung kira-kira $1.600 \mathrm{~m}$ (Gambar $6 \mathrm{~d}$ ). Padahal vegetasi di Batumadeg, lebih banyak tersedia makanan, daripada di Sebunibus ataupun Biaung. Diduga perpindahan Jalak Bali dari Batumadeg karena lokasinya terlalu tinggi sehingga kurang sesuai.

Pada tanggal 14-15 Mei 2012, Tim FNPF melakukan inventarisasi di Pulau Nusa Ceningan dan Pulau Nusa Lembongan. Tim tersebut menemukan Jalak Bali di Desa Lembongan (Pulau Nusa Lembongan). Selanjutnya, pada tanggal 20 Desember 2012, FNPF melepasliarkan enam ekor Jalak Bali di Pura Puaji Desa Jungut Batu (Pulau Nusa Lembongan) (Wirayudha. FNPF. Kom. Pri).

Keberadaan Jalak Bali di Pulau Nusa Lembongan, diduga dibawa oleh seseorang dari Pulau Nusa Penida. Kemungkinan yang dibawa itu adalah piyik Jalak Bali. Tujuan orang tersebut adalah agar di Pulau Nusa Lembongan juga terdapat Jalak Bali, sehingga dapat menjadi daya tarik ekowisata (Made Bombom Widana. FNPF. Kom.Pri).

Pada tahun 2012-2013, keberadaan Jalak Bali bertambah 4 lokasi (Lembongan, Pura Puaji, Biaung, dan Sebunibus) tetapi di Batumadeg tidak ditemukan burung tersebut lagi. Pada tahun 2012-2013 keberadaan Jalak Bali di Kepulauan Nusa Penida terdapat pada 10 lokasi, yaitu FNPF, Pura Penataran Ped, Pura Dalem ungkut, Pura Puseh, Sental Kawan, Pura Tinggar, Lembongan, Pura Puaji, Biaung, dan Sebunibus (Gambar d). Dengan demikian pada tahun 20122013, keberadaan Jalak Bali lebih banyak dibandingkan tahun 2008-2011 yang hanya 7 lokasi.
Pada tahun 2014 keberadaan Jalak Bali bertambah 2 lokasi, yaitu Sental Kangin dan Penida. Sental Kangin (134 m dpl) terletak 300 m selatan Sental Kawan, dan 300 m tenggara Pura Puseh. Diduga Jalak Bali di daerah tersebut berasal Sental Kawan dan Pura Puseh. Selain itu, Penida $(15 \mathrm{~m} \mathrm{dpl})$ terletak $1.000 \mathrm{~m}$ barat Sebunibus. Dua ekor Jalak Bali di daerah tersebut adalah burung pelepasliaran oleh Menteri Kehutanan Republik Indonesia pada tanggal 31 Desember 2013.

Keberadaan Jalak Bali di Kepulauan Nusa Penida pada tahun 2014 terdapat di FNPF, Pura Penataran Ped, Pura Dalem Bungkut, Pura Puseh, Pura Tinggar, Sental Kawan, Lembongan, Pura Puaji, Biaung, Sebunibus, Sental Kangin, dan Penida (Gambar 3e). Jadi pada tahun 2014, keberadaan Jalak Bali pada 12 lokasi lebih luas dibandingkan tahun 20122013 yang hanya 10 lokasi.

Pada tahun 2015 terdapat dua lokasi baru Jalak Bali di Kepulauan Nusa Penida, yaitu di Klibun dan Sakti. Klibun terletak $200 \mathrm{~m}$ tenggara Pura Puseh. Diduga Jalak Bali di Klibun berasal dari Pura Puseh. Sementara itu, desa Sakti terletak $500 \mathrm{~m}$ ke arah barat dari Sebunibus. Diduga Jalak Bali di Sakti berasal dari Sebunibus dan Biaung. Pada bulan Januari 2014, piyik Jalak Bali di Biaung mati dimangsa biawak (Varanus salvator). Akibat gangguan biawak tersebut, Jalak Bali pindah dari Biaung dan diduga ke Sakti yang berjarak sekitar $500 \mathrm{~m}$ ke arah barat.

Pada tahun 2015 keberadaan Jalak Bali di Kepulauan Nusa Penida terdapat di 12 lokasi, yaitu FNPF, Pura Penataran Ped, Pura Dalem Bungkut, Pura Puseh, Pura Tinggar, Sental Kawan, Lembongan, Pura Puaji, Sental Kangin, Penida, Sakti, dan Klibun (Gambar 3f). Selain itu, masih ada beberapa ekor Jalak Bali di sekitar Pura Puseh dan Klibun yang belum diketahui lokasi tinggalnya.

Dugaan Schmidt (1983) bahwa Jalak Bali pernah hidup di Pulau Nusa Penida adalah tidak benar. Berdasarkan wawancara dengan masyarakat di sekitar Pulau Nusa Penida, yaitu: Kotamadya Denpasar, Kabupaten Badung, Kabupaten Gianyar, Kabupaten Klungkung, dan Kabupaten Karangasem. Pada daerah-daerah tersebut tidak pernah ditemui Jalak Bali. Diduga distribusi Jalak Bali hanya di Kabupaten Buleleng, Tabanan, dan Jembrana. Sebelumnya di Kepulauan Nusa Penida tidak pernah ditemukan Jalak Bali, sampai FNPF melepasliarkan pada tahun 2006.

Di Kepulauan Nusa Penida, yang disebut Curik Nusa adalah Sturnus melanopterus (Jalak putih), bukan Jalak Bali. Jalak putih sekarang masih terdapat di Pura Puaji (Pulau Nusa Lembongan) dan Pura Dalem Bungkut (Pulau Nusa Penida). Menurut Collar dkk. (2001), distribusi Jalak putih di Pulau Nusa Penida adalah di Pundukaja, Karang Jawa, Sekartaji, Tanglad, dan di Pulau Nusa Ceningan.

Pada tahun 2006, di Batumadeg dilepasliarkan Jalak Bali sebanyak 25 ekor. Berdasarkan pengamatan pada tahun 2006-2008 terdapat 10 pasang Jalak Bali di Batumadeg yang berkembang biak. Sebaliknya, pada tahun 2009 Jalak Bali di Batumadeg tinggal 11 ekor dan pada tahun 2013 di Batumadeg sudah tidak terdapat Jalak Bali (Riany dan Aunurohim, 2013). Hal tersebut diduga karena lokasi Batumadeg yang berada di $239 \mathrm{~m}$ dpl terlalu tinggi bagi Jalak Bali, sehingga burung tersebut berpindah ke Biaung (105 m dpl), dan Sebunibus (155 m dpl).

Tercatat tahun 2012-2014, Jalak Bali di Sebunibus tidak berkembang biak. Bahkan, pada tahun 2015 Jalak Bali meninggalkan Sebunibus. Sebaliknya, Jalak Bali di Sental Kangin (134 m dpl), pada tahun 2014 berkembang biak sebanyak tiga kali. Oleh karena itu, diduga habitat yang sesuai untuk Jalak Bali adalah pada ketinggian 0-134 m dpl. Menurut 
Van Balen dkk. (2000) Jalak Bali adalah burung dataran rendah, tetapi dapat hidup di ketinggian 150-250 m dpl.

Distribusi Jalak Bali di Kepulauan Nusa Penida tahun 2006-2015 bertambah banyak, pada tahun 2006 jumlahnya 25 ekor dan pada tahun 2016 jumlahnya 66 ekor yang merupakan generasi kedua atau ketiga (Sudaryanto in pers). Pada tahun 2006 hanya pada 3 lokasi, tahun 2015 meluas paling sedikit menjadi 12 lokasi. Di samping itu ditemui kelompok baru Jalak Bali di sekitar Pura Puseh dan Klibun. Bertambahnya cacah individu Jalak Bali, menyebabkan terjadinya kompetisi dalam suatu kelompok (kompetisi intraspesies). Kelompok baru Jalak Bali dibentuk 2 sampai 4 ekor burung. Jarak antara lokasi lama dengan lokasi baru antara 100-300 m. Jalak Bali mudah mendapatkan lokasi baru karena vegetasi penghasil makanan burung tersebar merata dan makanannya tersedia sepanjang tahun.

Jadi di Kepulauan Nusa Penida Jalak Bali bertambah banyak sehingga lokasi distribusinya bertambah banyak. Keamanan burung terjamin dan vegetasi di Kepulauan Nusa Penida tersedia pakan sepanjang tahun.

\section{KESIMPULAN DAN SARAN \\ Kesimpulan}

Dari hasil penelitian ini dapat diambil kesimpulan sebagai berikut. Distribusi Jalak Bali di Kepulauan Nusa Penida bertambah luas. Pada tahun 2006 hanya 3 lokasi, sedangkan tahun 2015 paling sedikit 12 lokasi.

Saran

Jalak Bali adalah burung endemik Pulau Bali yang termasuk kategori kritis, diduga dalam waktu 10 tahun memiliki risiko kepunahan lebih dari 50\%. Agar konservasi Jalak Bali di Kepulauan Nusa Penida tetap berhasil dan semakin bertambah baik, maka habitat burung tersebut harus dijaga dan dilestarikan dan awig-awig tetap melindunginya.

\section{DAFTAR PUSTAKA}

Anonymous. 1999. Peraturan Pemerintah Republik Indonesia Nomor 7 Tahun 1999. Tentang Pengawetan Jenis Tumbuhan Dan Satwa. Presiden Republik Indonesia (http://www.dephut.go.id/INFORMASI/pp/7_99.htm). Diakses tanggal 1 Juni 2009.

2012a. Leucopsar rotschildi. The IUCN Red List of

Threated Species.

(http://www.iucnredlist.org/details/106006822/0).

Diakses tanggal 1 Desember 2012.

2012b. Convention on International Trade in

Endangered Species of

Wild Fauna and Flora.Appendices I, II and III. (http://www.cites.org). Diaksestanggal 1 Desember 2012.

Geografis.

2013. Klungkung Dalam Angka 2012 Keadaan

(http://www.klungkungkab.go.id/asset/file_bank/Klung kung\%20Dalam\%20Angka\%202012_Kondisi\%20Geog rafis.pdf). Diakses tanggal 16 Maret 2014.

Ardana, IP.G., Rukmana, N. 2017. Keberadaan Jalak Bali (Leucopsar rothschildi Strsemann, 1911) di Taman Nasional Bali Barat. Jurnal Simbiosis. 5(1): 1-6.

Collar, N.J., (Editor-in-chief), Andreev, A.V., Chan, S. Crosby, M.J.,

Subramanya, S.and Tobias, J. A. Maps by Rudyanto and Crosby, M. J.
2001. Threatened Birds of Asia: The BirdLife International Red Data Book. BirdLife International, Cambridge. 2369-2391.

Jepson, P. 2015. Saving a species threatened by trade: a network study of Bali starlingLeucopsar rothschildi conservation. Oryx. 49(2): 1-9.

Jepson, P., Ladle, R.J. 2005. Bird-keeping in Indonesia: conservation impacts and the potential for substitutionbased conservation responses. Oryx.39(4): 1-6. 2008. Developing new policy instruments to regulate consumption of wild birds: socio-demographic characteristics of bird-

keeping in Java and Bali. Oryx in press.

Jepson, P., Prana, M., Sujatnika, Amama, F. 2008. Developing a certification system for captive-bred birds in Indonesia. TRAFFIC Bulletin. 22(1): 7-9.

Riany, C.F., Aunurohim. 2013. Populasi Jalak Bali (Leucopsar rothschildi

Stresemann,1912 Hasil Pelepasliaran Di Desa Ped Dan Hutan Tembeling Pulau Nusa Penida Bali. Jurnal Sains dan Seni. POM. ITS. 2 (2): 2337-3520.

Schmidt, C. R. 1983. Jalak Bali (Leucopsar rothschildi). (http://www.cites.org/eng/resources/ID/fauna/Volume2/A227.051.013.001\%2 0Leucopsar\%20rothschildi_E.pdf). Diakses tanggal 20 Agustus 2010

Sodhi, N. S., Koh, L. P., Brook, B. W., Ng, P. K. L. 2004. Southeast Asian biodiversity: an impending disaster. TRENDS in Ecology and Evolution.19(12): 654-660.

Sodhi, N.S., Smith, K.G. 2007. Conservation of tropical birds: mission possible? J. Ornithol. 148:305-309.

Sudaryanto, Djohan, T.S., Pudyatmoko, S., Subagja, J. 2015. Behaviour Balistarling at Bali Barat National Park and Nusa Penida Island. Journal Veteriner. 16(3): 364-370.

Van Balen, B., Dirgayusa, I W. A., Putra, I M. W. A., Prins, H. H. T. 2000. Status

and distribution of the endemic Bali starling (Leucopsar rothschildi). Oryx. 34(3): 188-197.

Widodo, W. 2014. Komposisi Index Nilai Penting Burung dalam kaitan studi

Curik Bali (Leucopsar rothschildi) di Taman Nasional Bali Barat. Zoo Indonesia. 23(1): 21-34.

Wirayudha, N. B. 2007. Pelepasliaran Dan Perlindungan Burung Jalak Bali Di

Nusa Penida. FNPF. Nusa Penida. 